\title{
Anthelmintic Activity of Ethanol Extract of Polygonum minus Leaves against Ascaridia galli
}

\author{
Dara Agusti Maulidya ${ }^{1}$, Muhammad Ibnu Kahtan², Diana Natalia ${ }^{2}$, Mitra Handini ${ }^{3}$, Ari Widiyantoro ${ }^{4}$ \\ ${ }^{1}$ University of Tanjungpura, Faculty of Medicine, Pontianak, West Kalimantan, Indonesia \\ ${ }^{2}$ University of Tanjungpura, Faculty of Medicine, Department of Parasitology, Pontianak, West Kalimantan, Indonesia \\ ${ }^{3}$ University of Tanjungpura, Faculty of Medicine, Department of Physiology, Pontianak, West Kalimantan, Indonesia \\ ${ }^{4}$ University of Tanjungpura, Faculty of Mathematics and Science, Department of Chemistry, Pontianak, West \\ Kalimantan, Indonesia
}

\begin{abstract}
Objectives: Helminth infection is one of the main matters that cause health problems in developing countries. Polygonum minus are empirically used as an anthelmintic drug, but there has been no scientific study that proves it.

Methods: This study was aimed at determining the anthelmintic activity of ethanol extract of Polygonum minus leaves against Ascaridia galli in vitro. The extract was prepared in three different concentrations i.e $0.5 \mathrm{mg} / \mathrm{mL}, 1$ $\mathrm{mg} / \mathrm{mL}$ and $2 \mathrm{mg} / \mathrm{mL}$. $\mathrm{NaCl} 0.9 \%$ was used as a negative control group and albendazole $0.2 \mathrm{mg} / \mathrm{mL}$, a broad spectrum anthelmintic was used as a positive control group. Ascaridia galli was used as the test parasite. The study involved the determination of death time of the worms.
\end{abstract}

Results: The death time of the worms that caused by the extract concentration $0.5 \mathrm{mg} / \mathrm{mL}, 1 \mathrm{mg} / \mathrm{mL}$ and $2 \mathrm{mg} / \mathrm{mL}$, respectively were (mean $\pm S D$ ) $35 \pm 3.32$ hours, $32.8 \pm 2.39$ hours and $25 \pm 3.39$ hours. The death time that caused by negative and positive control group were $76.6 \pm 8.30$ hours and $19.2 \pm 1.48$ hours. There is no significant difference of death time of the worms between the extract concentration $2 \mathrm{mg} / \mathrm{mL}$ and the positive control group.

Conclusion: The anthelmintic activity of ethanol extract of Polygonum minus leaves has been confirmed and extract concentration $2 \mathrm{mg} / \mathrm{mL}$ has the same anthelmintic activity with albendazole $0.2 \mathrm{mg} / \mathrm{mL}$. J Microbiol Infect Dis 2018; 8(1):23-26

Keywords: Anthelmintic, Polygonum minus, Ascaridia galli, ascariasis

\section{INTRODUCTION}

Helminth infection is one of the major health problems in developing countries. World Health Organization (WHO) in 2012 reported about two billion people in the world has been infected by soil-transmitted helminthes (STH) [1]. The most common STH that cause helminth infection is Ascaris lumbricoides [2]. Ascariasis patients usually do not show any symptoms, but severe infection can cause food malabsorption, growth defect, even intestinal obstruction. Other symptoms may occur, such as fever, shortness of breath, cough and hemoptysis may occur as a result of allergic reaction caused by worm migration into lungs. This allergic reaction is called Loeffler Syndrome or Ascaris pneumoniae [3].

Albendazole and mebendazole are
recommended by WHO to treat STH infection
[4]. Although effective, these drugs have some
side effects, such as epigastrial pain, diarrhea,
headache, nausea, fatigue, dizzy, and insomnia.
These drugs are contraindicated for children
under 2-year old, pregnant women, and cirrhosis
patients [5]. Studies suggest that some
anthelmintic drugs are considered to have
decreasing effectiveness.[6]

Kesum leaves (Polygonum minus) is one of endemic plants from West Kalimantan which used by the civilians for seasoning and traditional medicine. Extensive study for various

Correspondence: Dr. Dara Agusti Maulidya, Faculty of Medicine, University of Tanjungpura, Jalan Prof. Hadari Nawawi,

Pontianak, Kalimantan Barat, Indonesia

E-mail: agustidara@gmail.com

Received: 29 January 2017 Accepted: 21 January 2018

Copyright (C JMID / Journal of Microbiology and Infectious Diseases 2018, All rights reserved 
pharmacological activities in Polygonum minus showed that it possesses high antioxidant activity, antimicrobial activity and analgesic activity [7]. Some substances in Polygonum minus leaves are thought to have anthelminthic effect, yet there is no further scientific studies to prove it. This is the first study that examines the anthelmintic effect of Polygonum minus leaves.

\section{METHODS}

\section{Ethics Statement}

The protocol and animal experimentation were approved by the Ethical Clearance Division of the Faculty of Medicine, University of Tanjungpura, Indonesia.

\section{Polygonum minus Leaves Extraction}

The leaves of Polygonum minus were collected from Kubu Raya Regency, West Kalimantan. The plant material was authenticated by Laboratory of Biology, Tanjungpura University, Indonesia. The leaves of the plant were washed, chopped and dried at room temperature for one week. The dried leaves were extracted with ethanol using maceration process for six days. The test of secondary metabolites revealed the ethanol extract of Polygonum minus leaves showed the presence of alkaloid, phenol, flavonoid, saponin, and tannin.

\section{Experimental Animals}

Adult roundworm (Ascaridia galli) was used to evaluate anthelmintic activity in vitro. Roundworms were obtained from the instestine of freshly slaughtered chicken. Infested intestines of chickens were collected from the local slaughter house and washed with normal saline solution to remove all the fecal matter.

\section{Anthelmintic Activity}

The anthelminthic assay was done to know the ability of ethanol extract of Polygonum minus leaves to kill worms. The use of Ascaridia galli species as a suitable model for screening of anthelmintic drug was advocated [8,9]. Extract was prepared at the concentrations $0.5 \mathrm{mg} / \mathrm{mL}$, $1 \mathrm{mg} / \mathrm{mL}$ and $2 \mathrm{mg} / \mathrm{mL}$ and five worms with approximately equal size were placed in each petri dish containing $50 \mathrm{~mL}$ of the test solution. Albendazole $0.2 \mathrm{mg} / \mathrm{mL}$ was used as reference standard due to its effect as a broad spectrum anthelmintic. Physiological solution, $\mathrm{NaCl} 0.9 \%$ was used as negative control to examine the life span of the worm in the external environment. All groups were incubated at controlled temperature $\left(37 \pm 1{ }^{\circ} \mathrm{C}\right)$.

All the test solution and standard drug solution were prepared freshly before starting the experiments. The motility of worm was observed every hour until all worms died. The mortality of worms were recognized by their straight flat appearance with no movements at the head and tail regions of the body after being touched using anatomical pinset and shaken vigorously. The data was analyzed with one-way ANOVA and Post-Hoc LSD test.

\section{RESULTS}

The death time of the worms that caused by the ethanol extract of Polygonum minus leaves concentration $0.5 \mathrm{mg} / \mathrm{mL}, 1 \mathrm{mg} / \mathrm{mL}$ and 2 $\mathrm{mg} / \mathrm{mL}$, respectively were (mean $\pm \mathrm{SD}$ ) $35 \pm$ 3.32 hours, $32.8 \pm 2.39$ hours and $25 \pm 3.39$ hours. The death time that caused by negative and positive control group were $76.6 \pm 8.3$ hours and $19.2 \pm 1.48$ hours. The result of worm mortality in this study showed that the increase of Polygonum minus leaves extract concentration is inversely proportional with the death time of worms. Complete observation result is explained in figure 1.

All groups with various concentration of extract $(0.5,1,2 \mathrm{mg} / \mathrm{mL})$ and standard drug (albendazole) showed a significant difference $(P<0.05)$ when compared to the negative control group $(\mathrm{NaCl} 0.9 \%)$. These show that all case groups being tested and positive control have anthelmintic effect. The test result suggested that treatment using concentration extract 0.5 $\mathrm{mg} / \mathrm{mL}$ and $1 \mathrm{mg} / \mathrm{mL}$ was significantly different $(p<0.05)$ by positive control, meanwhile treatment using concentration extract $2 \mathrm{mg} / \mathrm{mL}$ as case group with highest concentration have no significant difference $(p>0.05)$ by positive control. This suggested that ethanol extract from Polygonum minus leaves with concentration 2 $\mathrm{mg} / \mathrm{mL}$ has similar anthelmintic effect as albendazole $0.2 \mathrm{mg} / \mathrm{mL}$.

Correlation between two variables in this study was found using Spearman test. The result of Spearman test showed correlation coefficient 0.799 . This showed that ethanol extract concentration of Polygonum minus leaves and times of death of the worms have strong 
correlation. Significance score obtained from Spearman test is 0.000 , showed that ethanol extract concentration of Polygonum minus leaves and time of death of the worms have significant correlation. Correlation way obtained in correlation coefficient proved that correlation between two variables in this study is inversely proportional (correlation coefficient 0.799; significance score 0.000). This means that the higher ethanol extract concentration of Polygonum minus leaves, the faster worms' time of death occurred.

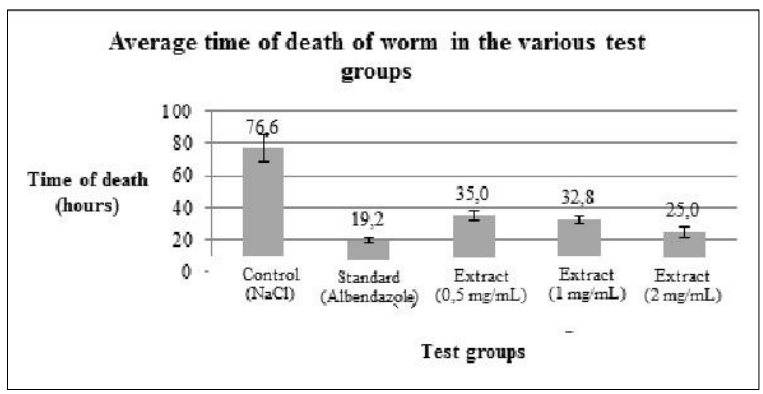

Figure 1. Average time of death of worms in the various test groups.

\section{DISCUSSION}

Worms' death from ethanol extract of Polygonum minus leaves exposure is caused by active substances which demonstrate toxicity towards worms. The result of secondary metabolites test showed that ethanol extract of Polygonum minus leaves contain alkaloid, phenol, saponin, and tannin. All these active substances are predicted to have roles in worms' death. Metabolite action of plants as anthelmintic could be additive, synergist, or antagonist action. These metabolites could play role in one or several target locations in worms. Each secondary metabolite has specific mechanism with following explanations.

\section{a. Tannin}

Tannin is an active substance which is able to precipitate protein and form strong complexes [10]. Anthelmintic activity in tannin happened because tannin wills denaturate proteins in worm body and cut oxidative phosphorylation bound which alter metabolism and homeostasis [11]. Tannin will bound to free proteins in digestive tract of worms or glycoproteins in cuticle which then causing physiologic impairments in motility, nutrition absorption, and reproduction $[12,13]$.

\section{b. Phenol}

Phenol mechanism in killing worms is by disturbing energy production process. Phenol will cause impairment of glycoproteins on cell surfaces by cutting oxidative phosphorylation bond [11].

\section{c. Alkaloid}

Alkaloid will work on central nervous system, impairing local homeostasis by reducing nitrates needed in protein synthesis and reducing sucrose distribution to small intestines [11].

\section{d. Saponin}

The effect of saponin is reducing surface tension from solvent so contact between extract and worm skin will be faster and effective [14]. Saponin also cause irritation on worm mucose membrane [14] and induced vacuolization and disintegration on worm tegument [11]. Saponin active substrate can obstruct cholinesterase enzymes and make worms suffered from muscle paralytic and spastic, then died [11].

The results of this study are in accordance with research conducted by Raza et al, who found that various medicinal plants showing in vitro anthelmintic activity, include Anacardium occidentale, Allium sativum, Tribulus terrestris, Bassia latifolia, Piper betle, Morinda citrifolia L.I, Cassia occidentalis $L$. and Aloe secundiflora.15 Medicinal plants appear to have good anthelmintic activities and may substitute conventionally used synthetic drugs, and their use may moderate drug resistance in endemic pathogen populations.

\section{CONCLUSION}

The anthelmintic activity of ethanol extract of Polygonum minus leaves has been confirmed and extract concentration $2 \mathrm{mg} / \mathrm{mL}$ has the same anthelmintic activity with albendazole 0.2 $\mathrm{mg} / \mathrm{mL}$.

\section{ACKNOWLEDGMENTS}

Conflict of interest: The authors declare no personal or financial conflict of interest.

Financial Disclosure: No financial support was received.

\section{REFERENCES}

1. World Health Organization. Soil-transmitted Helminthiases: Eliminating Soil-transmitted 
Helminthiases as a Public Health Problem in Children: Progress Report 2001-2010 and Strategic Plan 2011-2020. France: WHO Press; 2012.

2. De Silva, NR, Brooker S, Hotez PJ, Montresor A, Engels D, Savioli L. Soil-transmitted Helminth Infections: Updating the Global Picture. Trends Parasitol 2003;19:547-551.

3. Hall A, Hewitt G, Tuffrey V, de Silva N. A Review and Meta-analysis of The Impact of Intestinal Worms on Child Growth and Nutrition. Matern. Child. Nutr 2008; 4:118-236.

4. World Health Organization. Weekly Epidemiological Record 2014; 89 (13):133-140. Tersedia dari http://www.who.int/wer (Accessed in 09 October 2015).

5. Goodman LS, Brunton LL, Chabner B, Knollmann BC. Goodman \& Gilman's Pharmacological Basis of Therapeutics. $12^{\text {th }}$ ed. New York: McGraw-Hill; 2011.

6. Magill AJ. Hunter's Tropical Medicine and Emerging Infectious Diseases. $9^{\text {th }}$ ed. London: Elsevier; 2013.

7. Cristapher PV, Parasuraman S, Christina JMA, Asmawi MZ, Vikneswaran M. Review on Polygonum minus. Huds, a commonly used food additive in South East Asia. Pharmacognosy Res 2015; 7(1):1-6.

8. Vigar Z. Atlas of Medical Parasitology. $2^{\text {nd }}$ ed. P. G. Publishing House Singapore 1984; 242.

9. Dash GK, Suresh P, Kar DM, Ganpaty S, Panda SB. Evaluation of Evolvulus alsinoides Linn. For anthelmintic and antimicrobial activities, J Nat Rem 2002; 2: 182-185.

10. Makkar HPS. Antinutritional factor in food for livestock in animal producting in developing country. British Society of Animal Production. 1993;16:69-85

11. Jain P, Singh S. Anthelmintic Pontential of Herbal Drugs. Internatiol J Res Dev Pharm Life Sci 2013; 2:412-427.

12. Hoste $H$, Jackson F, Athanasiadou S, Thomsburg SM, Hoskin SO. The Effects of Tannin-rich Plants on Parasitic Nematodes in Ruminants. Trends in Parasitology 2006; 22:253-261.

13. Githiori JB, Athanasiadou S, Thamsborg SM. Use of Plants in Novel Approaches for Control of Gastrointestinal Helminths in Livestock with Emphasis on Small Ruminants. Veterinary Parasitology 2006; 139:308-320.

14. Tyler VE. Pharmacognocy. Philadelphia: Lea and Febiger; 1976.
15. Raza A, Muhammad F, Bashir S, Aslam B, Anwar MI, Naseer MU. In-vitro and in-vivo anthelmintic potential of different medicinal plants against Ascaridia galli infection in poultry birds. World's Poultry Science Journal. Cambridge University Press on behalf of World's Poultry Science Association; 2016; 72(1):115-124. 